\title{
Article
}

\section{Invited to labour or participate: intra- and inter-generational distinctions and the role of capital in children's invited participation}

Kiili, Johanna and Larkins, Cath

Available at http://clok.uclan.ac.uk/16845/

Kiili, Johanna and Larkins, Cath ORCID: 0000-0003-2999-6916 (2016) Invited to labour or participate: intra- and inter-generational distinctions and the role of capital in children's invited participation. Discourse, 39 (3). pp. 408-421. ISSN 0159-6306

It is advisable to refer to the publisher's version if you intend to cite from the work. http://dx.doi.org/10.1080/01596306.2016.1274290

For more information about UCLan's research in this area go to http://www.uclan.ac.uk/researchgroups/ and search for <name of research Group>.

For information about Research generally at UCLan please go to http://www.uclan.ac.uk/research/

All outputs in CLoK are protected by Intellectual Property Rights law, including Copyright law. Copyright, IPR and Moral Rights for the works on this site are retained by the individual authors and/or other copyright owners. Terms and conditions for use of this material are defined in the policies page. 


\title{
Invited to labour or participate: intra- and inter-generational distinctions and the role of capital in children's invited participation
}

\author{
Johanna Kiili $^{a *}$ and Cath Larkins ${ }^{b}$ \\ ${ }^{a}$ Jyvaskylan Yliopisto, Department of Social Sciences and Philosophy, Finland; \\ ${ }^{b}$ University of Central Lancashire; School of Social Work, Care and Community, \\ Preston, UK
}

\begin{abstract}
This paper applies aspects of Bourdieu's conceptual toolkit related to capital, and analyses inter- and intra-generational relations of influence. Applying Bourdieu's concepts to examples of case studies from a children's parliament in Finland, and with reference to an adult resident forum, moments of continuity and disruption in the relatively stable patterns of distinction between children and adults emerge. Children in school councils (at times) are labourers for agendas set by teachers, but the children at the top of the structure's hierarchy can benefit from cultural capital and a functional capital that enables them to set agendas and direct the work of others. The political capital of the person presenting views from the participation sphere and the dominant symbolic capital of market logics appear to have a greater impact than generation on the influence participants achieve. Unquestioned acceptance of this differentiation suggests that new approaches to invited participation structures are needed.
\end{abstract}

Keywords: children; participation; influence; inter-generational relations; capital; Bourdieu

\section{Introduction}

This paper explores the ambiguous potential of children's formal participation through analysis of intra- and inter-generational relations of influence over school and municipal resources by using examples from Tampere, a Finnish city at the forefront of European initiatives to promote invited spaces of collective participation for residents (Häikiö, 2010). In 2000, Tampere transformed local administration by taking a customer-orientated approach to service provision. The Tampere Children's Parliament (TCP), the first elected parliament in Finland for children aged 7-12 years, was also established. Later, in 2007, an adult residents' participation structure (the Alvari) was developed (Häikiö, 2010). In this article, focusing on a child structure, but drawing parallels with the Alvari adult structure, enables exploration of generation and other significant factors affecting children's influence in municipal decision-

${ }^{*}$ Email: johanna.j.kiili@jyu.fi 
making. Through this analysis, we respond to Hartung's (2015) suggestion that academics should find new 'productive and optimistic' ways to engage with practice and policy assumptions about children's relationships to power and needs for citizenship education.

Across Europe (Council of Europe, 2012; EU Commission, 2013), invited participation structures (such as pupil and youth councils where the membership, rules and methods are predetermined and formal) are advocated as a means of supporting children's rights ${ }^{1}$ to express their views. But invited participation structures can deepen domination through encouraging children's compliance with existing distributions of power, 'shifting attention away from increasingly aggravated social inequalities' (Arnot \& Reay, 2007, p. 312). Focus on formal spaces of participation can also detract from children's everyday practices that contribute to realising, challenging and reconfiguring their own rights and social relationships; this serves to frame citizenship as something children should learn about rather than something they exercise (Author, 2014a). Invited participation structures remain important, however, as they are a policy concern (Day et al., 2015); some children experience influence through them, in contrast with relatively constrained influence in their home or school lives (Cockburn, 2010); and they may provide children with links to formal political power over municipal or national resources (Wall, 2011). Reflecting on children's participation in Tampere responds to the need to link critique of adult and child invited participation structures (Tisdall, 2013; Wyness, 2013).

The article adopts a relational approach, advocated as a means of understanding child participation (see for example Mannion, 2007) which avoids conceiving of adults and children (and their governance structures) as fixed and polarized entities and enables understanding of moments of possibility. We start by introducing the current literature on children's invited participation and draw parallels with critiques of adult invited participation. We discuss the relevance of Bourdieu's (1977; 1986; $1990 ; 1994)$ concept of capital, and then introduce the methodology and empirical data. We describe the stated aims of the TCP (for children) and the Alvari (adult only). Using case examples, variations in distributions of capital that are valued and mobilized by members of the TCP are identified and links are drawn with the Alvari to aid understanding of differences and similarities in influence, between and within generations. We discuss the implication of these findings to enable challenging but optimistic engagement with future practice and relational theorising.

\section{Invited participation and the politics of participation}

Critiques of participation structures for children and young people tend to echo critiques of adult structures. Children and young people's participation structures are tokenistic, sometimes disempowering, used mainly for educational purposes, underrepresentative of disadvantaged young people and children, and channels for promoting neo-liberal self-governance and consumer driven subjects (Raby, 2014). There are therefore calls to refocus on participation as an interpersonal process of influence (e.g. Wyness, 2014); create 'radically pluralistic public arenas' (Cockburn, 2007, p. 454); and, use communication technologies to bridge 'public' and 'private' concerns (Cockburn, 2010). There is a preoccupation with participation as expressing views, and less emphasis on children's struggles for influence over decisions that affect them (Thomas, 2007). Children's participation structures tend to be disconnected from party politics, representational structures of government or school 
decision-making (Tisdall, 2010; 2013). Similarly, adult participation structures, such as expert advisory bodies and citizens' forums (e.g. Barnes, 2008; Cornwall \& Coelho, 2007; Häikiö, 2010) are part of this notionally non-party political invited participation sphere. They too are critiqued as exclusive, ineffectual, focused on the governance of conduct and diversions from formal political decision-making (Newman \& Clark, 2009; Coelho \& Cornwall, Cornwall \& Coelho in references 2007). Dialogue between child and adult invited participation spaces rarely occur.

To explore possibilities for influence, ${ }^{2}$ and connections between participation spaces, some theorization of the relational process of power has emerged. Mannion (2007, citing Alanen et al., 2007), argues that relational approaches provide a means of considering the generational processes of 'childing' and 'adulting', how and when children, adults, spaces and resources coincide to provide assemblages of practices, objects, places and people and the discursive and institutional conditions that allow different performances of participation. Gallagher (2008) suggests relevance of Foucault's account of power (pouvoir) as action exercised on the actions of others, through diverse networks of relations in localized and multi-scalar practices, which may or may have intended effects. Raby (2014) has applied Foucault to show how, alongside enabling children's co-optation in neo-liberal self-governance, in certain conditions, children's participation also has the potential to 'facilitate challenges to domination through the development of skilled subjectivities, despite emphases on self-government' (p. 82).

There is relative consistency in the sorts of attitudes, competencies and other resources that are mobilized through interpersonal relationships to enable children's influence over municipal resources. Key factors are a culture which respects children as competent citizens (Tisdall, 2010); clear aims and efforts focused on wellunderstood policy or practice opportunities and links between local participation structures and civil society groups (Crowley, 2014); opportunities for direct dialogue between all adult and child stakeholders (Raby, 2014); interdependent and intergenerational networks of connection between a variety of actors in school and home settings (Bjerke, 2011; Wyness, 2013); and time, money, equipment, food, transport and knowledge (Authors, 2014b).

Accounts of how these resources are distributed between different actors and institutions in wider social relations are also developing. Access to resources and opportunities are shaped by generational positions (Alanen et al., 2015) as well as class, gender and race. Children's access to resources is also related to market relations (Cockburn, 2010). Globalisation processes, that operate through education and play in Europe, affect the way children construct themselves and are constructed as citizens (Kjørholt, 2013), placing children in an inter-generational social order. However, participation can provide children with opportunities to destabilize generational and institutional patterns of inequality by equipping them with relevant capacities and opportunities (Raby, 2014). It remains crucial to investigate moments where, in contrast to dominant social relations, resources can be accessed and mobilized by children to exercise influence.

\section{The potential of Bourdieu for theorising children's participation}

Thomas (2007) proposed that Bourdieu's political sociology provides conceptual tools which may aid understanding of power and emphasises Bourdieu's ideas of social and cultural capital as this is what children 'often lack in relation to decision-making 
activity, and what they may gain from taking a greater part in it' (p. 212). Although there is substantial use of Bourdieu in sociology and education literature (e.g. Reay, 2000), there is scant application of Bourdieu's theoretical tools in existing literature on children's participation. Wood (2014) provides one example, and her focus is more on what children lack and can gain in terms of citizenship education rather than their influence. A full analysis would require interrogation of all socially significant positions of resident participation, situated within current relations and struggles within the broader political field, including the interrelations of capital and other factors between all actors. However, a focus on capital remains a useful starting point, Moore (2012) argues, as Bourdieu's concept of capital, and specifically symbolic capital, enables analysis of complementarity and variance within social groups, as well as between them. Turning Thomas's phrase on its head, Bourdieu's ideas on capital may therefore aid exploration of what some children have and others (children and adults) often lack in relation to influencing decision-making.

For Bourdieu, capitals are the embodied, objectified or institutionalized resources (for example, education, knowledge, assets, networks, institutional positions) and personal tastes and dispositions that social actors and social groups have accumulated and can mobilise to enable practices to have a greater chance of success (Bourdieu, 1977; 1986; Moore, 2012). A resource becomes a capital when it enables the holder to exercise social relations of power (Swartz, 2013). All forms of capital (e.g economic, social, cultural, political, physical) should be seen relationally; one form of capital can convert into another and the power of different capitals rise and fall in relation to each other (Swartz, 2013). The social groups who dominate a social space and who have more chances of success in achieving their goals, are those with the greatest concentration of the relevant capitals. Capital becomes symbolic capital when it is not recognized for what it is, a resource that can be exchanged, but is misrecognised by social actors and taken for granted as a legitimate reason for one person having authority (Bourdieu, 1986) or legitimate grounds for a privileged social position within a given social space (Bourdieu, 1994). Cultural capital (dispositions of the mind and body; objectified cultural and educational qualifications) is more likely to function as a symbolic capital because it tends to be seen as innate or earned through merit and the social conditions (inherited opportunities and economic advantages) which enable the accumulation of this form of capital tend to remain hidden (Bourdieu, 1986). Political capital is the symbolic capital of the social spaces (fields) of politics and can be embodied in individuals who develop substantial personal reputations and can be delegated to individuals by virtue of their position within an institution (Swartz, 2013). To understand a social space such as the State, Bourdieu continues (1986), it is necessary to explore interactions. We suggest this could extend to exploring the interactions within participation structures. This paper therefore develops a methodology for applying Bourdieu's conception of capital to explore intra- and inter-generational differences in moments of interaction within the social space of invited municipal participation.

\section{Methodology}

Primary research was focused on the TCP but we also gathered documentary evidence on the-adult structure Alvari. The TCP comprises, at its base, 41 primary schools in which children elect school councillors to attend school councils meetings, supported by facilitating teachers. The second tier, general meetings (GM), is a quasi- 
representative structure that meets twice a year attended by 'GM representatives' These are school councillors elected (by fellow children) or selected (by teachers) on the basis of perceptions of their civic competence. GM representatives vote in the upper-tier of the TCP, comprising 15 board members elected for a two-year period. Their twice monthly meetings are facilitated by the TCP facilitator. Fieldwork involved thematic and semi-structured interviews with 27 children aged 9 to 12 years, facilitating teachers, the TCP facilitator, and two local ombudsmen for children. Observations were also made at three GMs, eight board meetings, three councillor training days, and one teacher training day. The interviews and observations were conducted by the first author from April to December 2010 and March to October 2012.

To situate the TCP within the broader field of municipal decision-making, documents on governance in Tampere including brochures, reports and minutes, were retrieved through searches on the webpages of the city of Tampere (e.g. Tampere, 2004; 2007; 2008). To extend the possibilities for inter-generational analysis, we sought an adult-invited participation structure with broadly similar relationships to municipal decision-making as the TCP.

Through thematic analysis (Braun \& Clarke, 2006) of the primary research in Finnish descriptions of the data related to the invited structure, actors and resources were identified and translated into English (as the second author does not read Finnish). From the Tampere documents, in English and Finnish, the authors mapped out the discourses of invited resident participation and governance, the key actors and their relations as well as the stated aims of the participation practices. Through dialogue the authors identified differences between the three tiers of the TCP structure as well as commonalities and differences between the upper tiers of the TCP and published accounts of other Tampere participation structures. The Alvari appeared most relevant as it physically meets and informs decision makers (Häikiö, 2010). Unlike the TCP, there are no elections but Alvari members, nominated by local associations and organisations, are selected by the City Board (chaired by the Mayor). In addition, any residents of the local area may self-select themselves into the structure by signing in as members when they attend the Alvari meetings. The Alvari, facilitated by a participation worker from the Local Democracy Unit (LDU), meet four or five times a year in five local areas of Tampere.

Following Bourdieu (1986; 1990) and Emirbayer \& Williams (2005), we engaged in a circular process of identifying the attitudes and social and cultural resources mobilised in different practices; exploring different key actors' relationships to these, and to wider distributions of resources; and, focusing on what might be considered as capital, enabling the influence of child and adult 'representatives' within these structures. When analyzing the data we have aimed to neutralise and analyse the power of dominant discourse, to see behind that (Bourdieu, 1999) and to question apparently accepted symbolic legitimacy or value flowing from different capitals.

\section{Findings}

Age-based distinctions are apparent in the aims and functioning of the TCP and the Alvari, however generational divisions within the invited participation sphere are less explicit than in municipal elections, where children are completely excluded. The municipal aims for both the TCP and the Alvari are to provide information to children or residents and to gather views to inform city officials and service providers about 
the needs of customers. Children's responsibility to educate themselves by developing key citizenship skills is also emphasized and this aim is embraced by TCP Board members as they talked of it being 'important to learn these things, like how meetings are run and so forth'. Although the duty flowing from the UNCRC for all municipal administrations and service providers to listen to children is underlined, the documents also refer to the aim for children to feel successful in having their say (CoE, 20112012 in refs). The TCP representatives are described as autonomous and self-determined individuals who are 'the voice of children in Tampere' (Jotos, 2009, p. 33) and 'represent peers, defend positions and make a difference' (Tampere, 2004, pp. 14-16). In contrast, the Alvari should 'make it easier for residents to ... influence the planning processes of their own environment and services' (Tampere, 2008, p. 8) and there is no discourse of education for civic competence.

Rather than the feeling of having a say proposed for TCP members, the municipal documents proposes the Alvari as a means of enabling influence. Age may then be a relevant embodied capital, as by virtue of age, official discourse recognises adults as competent to influence whereas children (by virtue of their lack of age) need to develop civic competence. However, this contrast may only exist in discourse, as Häikiö (2010) concludes that adult residents remain on the margins of political influence in municipal decision-making in Tampere; they are not conceived as 'agents constructing political issues and fighting for them' (p. 381). As age does not guarantee influence in the invited participation sphere, the similarities and differences between children, and between some children and some adults are explored in three case studies below, where we identify patterns of relationships to relevant capitals in school, substance misuse prevention and health-related decision-making.

\section{School: influence over use of labour and other resources}

As in previous research (de Castro, 2012), in the TCP children's greatest scope for influence in school councils was usually through planning and executing special events, such as discos, campaigns and talent-days. In these contexts children had permission to make decisions about the use of resources but the emphasis on organizing different predefined and obligatory events was criticised. Two TCP board members described school councillors as 'labour' for teachers and some facilitating teachers described councils as 'kind of a program agency who will do all the extra events in school'. To draw on Bourdieu's conceptual tools, we could say that the economic capital represented by children's labour is not directed by children themselves, as they do not have the authority to determine the use of it, although they can resist or challenge the authorities. This critique has of course been raised in relation to the work children do in schools producing themselves as human capital (Oldman, 1994). The school councillors did not question control of labour within schooling per se, but they critiqued the extent to which providing labour for a goal that is set externally, by those in authority, should be interpreted as influence.

A contrast emerges between children in the school councils and those in the middle and particularly the upper tiers of the TCP. In these spaces some children did direct the goals towards which collective resources (e.g., knowledge and labour) could be used. By virtue of their position within the formal structure, the 15 board members decided general meeting agenda items. 
That is the reason I applied to the board of the TCP, because here we can plan and decide much more ourselves (than in school councils). (TCP Board member, girl, 11 years)

In one example, the board members used their position to put the issue of school lunches on the GM agenda, the GM discussed and approved a programme of research and this was conducted with labour provided by school councillors. Position on the board also enabled direct communication with the service provider and politicians involved in commissioning and using the knowledge gained through the research. Time, physical spaces, and the networks and support of the TCP facilitator and the ombudsman may have enabled board members to lobby in the way that some adult policy actors do (Gale, 2003) and they succeeded in bringing about the school meal changes they sought.

As Gallagher (2008) describes, in the TCP there is evidence of power being exercised over the actions of others, by some adults and some children. Institutional positions, accepted as legitimate by all observed actors, gave TCP board members an unquestioned right to set agendas, direct the actions of the TCP facilitator, 'represent the views of children' and to make decisions about the TCP 10,000 Euro budget. Board members therefore appeared to have an institutional position associated with a kind of political authority or delegated political capital (Bourdieu, 1991 Not in refs, cited in Swartz, 2013) as they could direct the use of the TCP economic, social and cultural capital and act as representatives of children's views. In setting the agenda and directing the use of TCP resources to conduct research through school councillors, these children had a similar relationship to capital as senior teachers within schools. This is a form of 'functional capital' for performing 'organizationally sanctioned tasks' delegated to government officials as well as teachers (Bourdieu, 1991, cited in Swartz, 2013, p. 76). Our data does not enable us to identify whether any institutional positions also enabled Alvari members to direct the use of any resources within their networks, but it was clear that unlike the TCP board, the Alvari members had no independent budget.

\section{Substance misuse prevention: inter- and intra-generational complicity and resistance}

Although board members delegated political capital enabled them set TCP agendas, they were also lobbied by adults with other agendas which they accepted or rejected, revealing complex intra- and inter-generational dynamics (Authors, 2013). In one instance, the TCP board appeared to collaborate with some adults to pursue a protectionist agenda that was unpopular with the wider group of GM representatives. A parents' group asked the TCP board to support a sticker-based campaign aimed at encouraging shops to not sell alcohol or tobacco to minors. The board agreed to put the campaign on the TCP agenda and GM representatives gave initial support. However, when the campaign was later reviewed, at least eight GM representatives voiced criticisms:

This is already illegal, so why are you using money on stickers? (GM representative)

Calls were made for the city's preventive unit to use their budget for things that directly benefit all children, for example, cycle tracks. The board members' 
statements, however, were all in favour of the campaign goals, as were those of City officials:

It is really important to prevent alcohol use by children and young people. We have had great co-operation with the board this year. (City official)

The issue was not put to a vote and the campaign continued.

The extent to which the board members were explicitly ignoring GM

representatives' views to influence the continuation of this campaign is unclear. Board members may have been mobilising cultural capital (their knowledge of voting procedures) to not call for a vote, or the lack of a vote, may have been accidental. We do know that, as the TCP facilitator reflected afterwards, the modus operandi and the possibility to call for a vote was not familiar to those GM members who presented critical views. The tension between empowerment and compliance here recalls

Foucault's (1978 Not in refs, cited in Raby, 2014) suggestion that the power of social institutions and individuals are mutually interdependent and interact in such instances. From a Bourdieusian perspective, board members' political and cultural capital may then have combined with protectionist attitudes of other key actors rendering ineffective the resistance of the GM representatives who had less significant cultural and political capital.

The fact that board members are again in the position of exercising or benefiting from influence over decision making demands attention to the distributions of social and cultural capital (Bourdieu, 1986) that enabled them to become (s)elected to these positions. Echoing De Castro's (2012) findings, children who were older and had popularity (social networks) and broadly defined civic competence (maturity, school competence, and knowledge of democratic practices) were most likely to get elected up through the tiers of the TCP. The cultural capital of civic competence is symbolic capital as differentiation between children on the basis distributions(?) of this capital is taken for granted and promoted within the participation sphere and municipal discourse. The symbolic value of this capital also appears to have relevance for the Alvari, as the Alvari tend to include those who are active in civic associations (Haapoja, 2013) where they are likely to have developed experience of formal meetings.

Observing symbolic capital is not however to say that those children who did gain the distinction of becoming TCP board members are consciously mobilising their accumulated capital to promote their own domination. TCP board members and school councillors expressed the wish to represent others, stating that 'not everybody is interested, but maybe we should still ask their opinions more'.

\section{Health: adult, mayoral or budgetary privilege?}

As civic competence is a symbolic capital and an assumed feature of adulthood, it is useful to explore an example of where representing adult (as opposed to child) views may convey relatively greater symbolic value. In two concurrent examples of attempts to influence a health-related decision, the TCP and the Alvari received contrasting responses. The TCP lobbied for more school health professionals; however, the Ombudsman who heard their views (and described herself as 'a children's rights lobbyer') said she was constrained by budget cuts. Following her attendance at the purchasing committee, there was no change in this service. The Alvari made 
recommendations regarding health counselling and preventive services and facilitating staff from the Local Democracy Unit (LDU) sent the Alvari's suggestions to the relevant committee and to the deputy mayor. Money was subsequently allocated to create a pilot mobile health bus for senior residents offering drop-in services and information.

As the Alvari was successful, it is tempting to suggest that adulthood is associated with more influence in municipal health decisions, but in lobbying activities two years prior to this the TCP had been successful in securing more health resources for school. Institutional positions and attitudes unrelated to generation are significant here. The deputy mayor, who received and represented the Alvari's suggestions, was also the chair of the committee that made the decision to allocate funds. The Ombudsman tasked with representing the TCP views has a more complicated institutional position. In the committee for children and youth services, she must both represent children's views and prepare the yearly agreement on children and young people's health services. She describes the inherent tension and ethical dilemmas of this position:

We had the need to save money. And at the same time I worked with the TCP board and I did listen to their opinions in General Meetings where they were saying that we need more school nurses. And during this spring I, as the deputy ombudsman, am proposing that the city cuts the health expenses by the sum of 360000 euros. This is ethically unbearable.

The institutional position (political capital) of those representing and potentially advocating for their views appears to be significant. But the accepted need to cut expenditure also appears to reflect another unquestioned logic in the form of market (austerity) logics and this is echoed in the TCP aim of children developing entrepreneurial skills.

\section{Discussion}

The current literature on children's invited participation demands a focus on intergenerational relations within the child participation sphere (e.g. De Castro, 2012; Mannion, 2010; Wyness, 2013). Our inter-generational analysis in this paper is limited, as we did not conduct field research in the spaces of invited adult participation and consequently the data we used was not comparable. However, our analysis does stretch into the adult invited participation sphere by using contemporaneous written documents to show instances of differential value placed on capitals that adults and children mobilise to achieve influence within the invited participation sphere. Within the limits of the data, using Bourdieu's conceptions of capital, enabled us to unpick 'children', 'adults', and 'residents' and see not only social groups or representatives, but rather groups within social groups. Beyond exploring distributions of capital relevant to participation between individual children (Wood, 2014), Bourdieu's political sociology has provided a way of looking at the intersectionality of participation layers and of identifying the valued resources which can be seen as capital because they are mobilised by and constrain actors chances of success in achieving their goals. Age, civic competence, social networks, institutional positions, and market logics are all significant factors that can be seen as relevant capitals in the space of invited participation. Identifying symbolic capital provides ways of revealing and potentially reversing the hidden impact of these structures in perpetuating the domination of particular groups of children. 
From an inter-generational perspective, the social position of 'child' compared to 'adult' was distinguished not only by legal rights (e.g., right to vote) but also assumptions about competencies. Adults were assumed to have the cultural capital (civic competence including maturity) which children needed to learn in order to advance within the TCP hierarchy. The unquestioned symbolic value of this capital within the child participation sphere reinforced generational distinctions, and exacerbated disadvantages based on individual children's age and social and cultural capital. These are likely to be linked to social class (Authors 2015). The focus on civic competence may also disadvantage those adults who feel they do not have the relevant civic competence to join the Alvari. The widespread acceptance of this distinction as a legitimate reason for differentials in opportunities to successfully pursue one's goals suggest it is symbolic capital.

These intra-generational differences indicate the existence of different groups within the social group 'children'. And, within the participation sphere, those children in higher tiers of the TCP had some similarities with relatively advantaged adults. Board members were found to have a kind of delegated political capital enabling them to influence agendas, the actions of others, and use of economic, social and cultural capital. This position was similar to that of city officials and senior teachers, in that board members were able to mobilise their political capital to influence the goals that economic capital (children's labour) was used to achieve. These children's opportunities to develop civic competencies in relation to familiarity with standard civic procedures like debating and voting may also have provided them with 'skilled subjectivities' (Raby, 2014, p. 82) which enable some children to dominate others through interactions of their individual and institutional (and adult protectionist discourse) powers. Inter-generational similarities were therefore observed between some children and some adults.

The findings call for attention to the concept of delegated political capital (Bourdieu, 1991, in Swartz, 2013) in analysis of both child and adult invited participation. The legitimacy of board members' political capital associated with their elected positions was unquestioned by children involved in the TCP, even though board members at times ignored the dissenting views of other children. Their delegated political capital may have added to the value city officials placed on the views expressed by these children, particularly in a context where customer views and formal structures are valued. The importance of focusing on political capital is underlined by the fact that it also enables influence by senior teachers and government officials and politicians to direct children's labour and municipal budgets.

When the aim of children's invited participation is, as Wall (2011) suggests, to enable children to exercise influence over municipal resources, embracing opportunities for any children to gain political capital remains appealing. However, Swartz (2013) describes the risk of actors getting caught up in the logic of a political space and then 'unwittingly help create and solidify bounded political options rather than create new alternatives' (p. 71). This can be avoided by focusing on how the symbolic legitimacy of any political capital any children or adults accrue through the delegated authority of their institutional positions, can be distributed to enable dominated children and adults to exercise influence on issues that concern them.

These findings have challenging relevance for the development of participation structures across Europe, but applying this learning would provide more optimistic futures (Hartung, 2015). The role of selective and hierarchical structures such as the TCP must be questioned as they perpetuate inequalities and act as mechanisms for 'ensuring that children will ... internalise disciplinary aims and shape themselves in 
accordance with expected social norms' (Raby, 2014, p. 81). A broad range of child and adult views could be achieved through non-hierarchical open fora, organising using appropriate communication tools for the participants, rather than imposing an expectation of civic competence and formality that are exclusive and perpetuate domination. In the interests of transparency, children who are deciding whether to take part in hierarchical formal structures should be informed that by entering the participation sphere they may be doing two things: first, giving up some control over the use of their own time (economic capital); and second, delegating authority over their time to institutionalised decision-making, in which only some (usually relatively skilled, popular and elected) children and some (senior teacher, politician, official or purchaser) adults exercise influence. Once they are more informed, these children may also become more inclined to challenge this orthodoxy by demanding that political capital is delegated to the general meeting or open forum and by holding accountable, or recalling (Wall, 20102011 in refs) child representatives in higher layers of the structure. Adults might also benefit from reflecting on these issues when they participate in structures where power is delegated.

\section{Conclusion}

Studies of children's participation involving comprehensive and detailed empirical analysis of different contexts and actors are developing, as is understanding of intersectionality and the exercise of power between and among generations (e.g., Kallio, 2016; Phillips \& Tossa, 2016). This article contributes to the emerging literature and has relevance across European contexts within and outside of educational settings. The common policy discourse that participatory fora will automatically open up channels for effective dialogue between the state and citizens (see also Cornwall \& Coelho, 2007) is not convincing. Participation structures are being recommended in pan-European policy, without sufficient attention to how such structures can ensure younger or disadvantaged children's perspectives are taken seriously and result in their influence over social resources, rather than just voice or complicity in self-governance. To understand whether and by what means participation structures might achieve this, critical analysis of children's and adults' relationships to relevant resources, institutional positions and relations of production in the participation processes is necessary. To be realised, these developments would require a seismic shift in conception of children's and adults' competence and definitions of the appropriate rights, responsibilities and relationships to resources of adult and child citizens. Rather than focusing on children's need to learn citizenship, it would mean acknowledging all children's and adult's competence not only to express a view but also to enact decisions about social resources, enabling them to challenge the value and symbolic power of civic competence. In time, this might reframe the purpose of invited participation structures so that they become a means of deciding together, not just a means of appearing to listen.

\footnotetext{
Notes

${ }^{1}$ Described, for example, in Article 12 of the UN Convention on the Rights of the Child (1989).

${ }^{2}$ We use the term influence in this article, as this echoes the terminology in the UN Convention, however theories of power are essential for understanding what this can mean.
} 


\section{References}

Alanen, L., Brooker, L., \& Mayall, B. (2015). (Eds.) Childhood with Bourdieu. Palgrave Macmillan. Arnot, M., \& Reay, D. (2007). A sociology of pedagogic voice: Power, inequality and pupil consultation. Discourse: Studies in the cultural politics of education, 28(3), 311-325.

Barnes, M. (2008). Passionate participation: Emotional experiences and expressions in deliberative forums. Critical Social Policy, 28(4), 461-481.

Barnes, M., Newman, J., \& Sullivan, H. (2007 Not cited in text). Power, participation and political renewal: Case studies in public participation. Bristol, UK: Policy.

Bjerke, H. (2011). 'It's the way they do it': Expression of agency in child-adult relations at home and school. Children \& Society, 25(3), 93-103.

Bourdieu, P. (1977). Outline of a theory of practice. Cambridge: CUP.

Bourdieu, P. (1986). The forms of capital. In J. G. Richardson (Ed.), Handbook of theory and research for the sociology of education (pp. 241-258). New York: Greenwood Press.

Bourdieu, P. (1990). The logic of practice. Stanford, CA: Stanford University Press.

Bourdieu, P. (1994). Raisons pratiques: Sur la théorie de l'action. Seuil: Paris.

Bourdieu, P. (1999). Understanding. In P. Bourdieu et al. (Eds.), The weight of the world: Social suffering in contemporary society (pp. ??-??). Cambridge: Polity Press.

Braun, V., \& Clarke, V. (2006). Using thematic analysis in psychology. Qualitative Research in Psychology, 3(2), 77-101.

Cockburn, T. (2007). Partners in power: A radically pluralistic form of participative democracy for children and young people. Children \& Society, 21(6), 446-457.

Cockburn, T. (2010). Children and deliberative democracy in England. In B. Percy-Smith, \& N. Thomas (Eds.), A handbook of children and young people's participation: Perspectives from theory and practice (pp. 306-317). London \& New York: Routledge.

Cornwall, A., \& Coelho, V. S. P. (2007). Spaces of change? The politics of participation in new democratic arenas. In A. Cornwall, \& V. S. P. Coelho (Eds.), Spaces for change? The politics of citizen participation in new democratic arenas (pp. 1-29), London \& New York: Zed Books.

Council of Europe (CoE). (2012). Recommendation CM/Rec (2012)2 of the Committee of Ministers to member States on the participation of children and young people under the age of 18. Strasbourg: Council of Europe.

Crowley, A. (2014). Evaluating the impact of children's participation in public decision-making. In J. Westwood, C. Larkins, D. Moxon, Y. Perry, \& N. Thomas (Eds.), Citizenship and intergenerational relations in children and young people's lives: Children and adults in conversation (pp. 29-42). Palgrave Pivot: Basingstoke.

Day, L., Percy-Smith, B., Ruxton, S., McKenna, K., Redgrave, K., \& Young, T. (2015). Evaluation of legislation, policy and practice on child participation in the European Union (EU): Research Summary. Brussels: European Commission. Retrieved from http://bookshop.europa.eu/en/evaluation-of-legislation-policy-and-practice-of-child-participationin-the-eu-pbDS0614240/

De Castro, L. R. (2012). The 'good enough society', the 'good enough citizen', and the 'good enough student': Where is children's participation agenda moving to in Brazil? Childhood, 19(1), 52-68. 
EU Commission. (2013). Recommendation investing in children: Breaking the cycle of disadvantage. Brussels: European Commission, 20.2.2013 (C(2013) 778 final). Retrieved from http://ec.europa.eu/justice/fundamental-rights/files/c_2013_778_en.pdf

Emirbayer, M., \& Williams, E. M. (2005). Bourdieu and social work. Social Service Review, 79(4), 689-724.

Gale, T. (2003). Realising policy: The who and how of policy production. Discourse: Studies in the Cultural Politics of Education, 24(1), 51-65. DOI: 10.1080/01596300303026

Gallagher, M. (2008). Foucault, power and participation. The International Journal of Children's Rights, 16(3), 395-406.

Haapoja, M. (2013). Resident participation in Tampere. A survey for city officials [Kuntalaisten osallistumisen järjestämisen nykytilanne virkamiesnäkökulmasta]. City of Tampere: Local Democracy Unit

Hartung, C. (2015). Global citizenship incorporated: Competing responsibilities in the education of global citizens. Discourse: Studies in the Cultural Politics of Education, DOI: 10.1080/01596306.2015.1104849

Häikiö, L. (2010). The diversity of citizenship and democracy. Local Public Management Reform, Public Management Review, 12(3), 363-384.

Jotos. (2009). Handbook for children's and young people's participation [Jotos - polku osallisuuteen]. Tampere 2009. Published by?

Kallio, K. P. (2016). Shaping subjects in everyday encounters: Intergenerational recognition in intersubjective socialisation. Environment and Planning D: Society and Space. Published online June 15, 2016, DOI: 10.1177/0263775816654916.

Kjørholt, A. T. (2013). Childhood as social investment, rights and the valuing of education. Children \& Society, 27(4), 245-257.

Mannion, G. (2007). Going spatial, going relational: Why ‘listening to children' and children's participation needs reframing. Discourse: Studies in the Cultural Politics of Education, 28(3), 405-420.

Mannion, G. (2010). After participation: The socio-spatial performance of intergenerational becoming. In B. Percy-Smith, \& N. Thomas (Eds.), A handbook of children and young people's participation: Perspectives from theory and practice (pp. 330-342). London \& New York: Routledge.

Moore, R. (2012). Capital. In M. Grenfell (Ed.), Pierre Bourdieu: Key concepts (pp. 98-113). Durham: Acumen.

Nash, R. (1990 Not cited in text). Bourdieu on education and social and cultural reproduction. British Journal of Sociology of Education, 11(4), 431-447, DOI:10.1080/0142569900110405.

Newman, J., \& Clarke, J. (2009). Publics, politics and power: Remaking the public in public services. Los Angeles \& London: SAGE.

Oldman, D. (1994) Childhood as a mode of production. In B. Mayall (Ed.), Children's childhoods observed and experienced (pp. 153-166). London: Falmer.

Phillips, L. G., \& Tossa, W. (2016). Intergenerational and intercultural civic learning through storied child-led walks of Chiang Mai. Geographical Research, Advance online publication. DOI: 10.1111/1745-5871.12182

Raby, R. (2014). Children's participation as neo-liberal governance? Discourse: Studies in the Cultural Politics of Education, 35(1), 77-89.

Reay, D. (2000). A useful extension of Bourdieu's conceptual framework? Emotional capital as a way of understanding mothers' involvement in their children's education? The Sociological Review, 48(Issue?), 568-585. DOI:10.1111/1467-954X.00233 
Swartz, D. (2013). Symbolic power, politics, and intellectuals: The political sociology of Pierre Bourdieu. Chicago \& London: University of Chicago Press.

Tampere (2004). Action plan for educational service. [Kohti osallistuvaa toimintakulttuuria Tamperelaisissa kouluissa, oppilaitoksissa ja nuorisotiloilla.] Tampereen kaupunki, Koulutustoimialan raporttisarja 7/2004.

Tampere (2007). The new management model in Tampere.

Retrieved from

http://www.tartu.ee/kultuurikonverentsid/2006/strategy/stratfiles/esiteEnglanniksi.pdf

Tampere (2008). Evaluation of the pilot-project Alvari. Vaivan väärtti. [Tampereen alueellisen osallistumisen mallin pilotin arviointi.] Retrieved from http://www.tampere.fi/liitteet/5Bi19pHmh/Alvarin_arviointi_-_2008.pdf

Thomas, N. (2007). Towards a theory of children's participation. International Journal of Children's Rights, 15(2), 199-218.

Tisdall, E. K. M. (2010). Governance and participation. In B. Percy-Smith, \& N. Thomas (Eds.), A handbook of children and young people's participation (pp. 318-329). London: Routledge.

Tisdall, E. K. M. (2013). The transformation of participation? Exploring the potential of 'transformative participation' for theory and practice around children and young people's participation. Global Studies of Childhood, 3(2), 183-193.

Wall, J. (2011). Can democracy represent children? Towards politics of difference. Childhood, 19(1), $86-100$.

Wood, B. E. (2014) Participatory capital: Bourdieu and citizenship education in diverse school communities. British Journal of Sociology of Education, 35(4), 578-597. DOI: 10.1080/01425692.2013.777209.

Wyness, M. (2013). Children's participation and inter-generational dialogue: Bringing adults back into the analysis. Childhood, 20(4), 429-442.

Wyness, M. (2014). Children, family and the state: Revisiting public and private realms. Sociology, $48(1), 59-74$ 